Михайлишин Г., Довга М. Аналіз життєвих проблем молодих сімей у суспільстві

УДК 316.614.5

DOI https://doi.org/10.24919/2308-4863/34-4-31

Галина МИХАЙЛИШИН, orcid.org/0000-0001-7038-057X доктор філософських наук, професор, проректор з науково-педагогічної роботи Прикарпатського національного університету імені Василя Стефаника (Івано-Франківськ, Україна) halyna.mykhailyshyn@рпи.еdu.ua

Мирослава ДОВГА, orcid.org/0000-0003-0564-123X аспірант кафедри теорії і методики дошкільної і спеціальної освіти Прикарпатського національного університету імені Василя Стефаника (Івано-Франківськ, Украӥна) тіrosya29@meta.ua

\title{
АНАЛІЗ ЖИТТЕВИХ ПРОБЛЕМ МОЛОДИХ СІМЕЙ У СУСПІЛЬСТВІ
}

На нинішньому етапі розвитку украӥнського суспільства відбулися відповідні трансформаційні зміни в різних його суспільних інститутах, серед яких найбільш вразливими є інститут молодої сім'ї. Трансформаційні зміни серед молодих сімей проявляються в осередку збереження та відновлення сімейних иінностей, збільшенні кількості розлучених сімей, позашлюбної народжуваності, зниженні життєвого рівня сімейного життя, оскільки саме молоді сім'ї найбільш швидко та болісно реагують на такі зміни викликані зовнішніми обставинами, щзо, відповідно, породжують внутрішні сімейні суперечності. А изе своєю чергою призводить до появи низки сімейних проблем, які є взаємопов'язаними та випливають одна на одну. Тому нами розглянуто та проаналізовано проблеми, які виникають у молодих сімей: функціональні проблеми (матеріально-економічна, житлово-побутова, репродуктивна, комунікативна, виховна, рекреативна), проблеми становлення молодої сім'ї (проблема створення, збереження та розширення сім ’ï), проблема появи конфлікту та одна із найважливіших проблем - соціальноправовий захист молодих сімей із боку держави.

Розглянуто систему соиіально-правового захисту інституту сім'ї в інших розвинених країнах, адже ия система включає в себе звичайні мінімальні гарантії та заходи з економічної стабільності молодих сімей. Проаналізовано сочіально-правовий захист в украӥнському суспільстві, який треба розширити, врегулювати та реалізувати на законодавчому рівні, оскільки без продуманої сімейної політики та захисту сімей не варто очікувати позитивні зміни в інституті сім 'ï.

Наведено статистичні дані опитуваних молодих сімей ум. Івано-Франківськ щуодо проблем, які, на їхню думку, найбільи притаманні молодим сім'ям, та проблем, які є в їхній сім'ї. Ці проблеми в молодих сім'ях зводяться до неналежного рівня здійснення соиіально-правового захисту, через щзо і виникає низка усіх інших сімейних проблем.

Побудовано піраміду проблем молодих сімей, де показано проблеми зверху до низу, які виникають у молодих сім'ях, та взаємозв'язок між ними. На вериині піраміди проблем молодих сімей знаходиться соиіально-правовий захист як основа захисту інституту сім'ї, за яким проблеми молодих сімей розташовані в такому порядку: проблема появи конфлікту, проблеми становлення сім'ї, функціональні проблеми, як тягнуть за собою низку усіх іниих сімейних проблем.

Ключові слова: функиії сім ’̈, молоді сім '̈̈, проблеми молодих сімей, піраміда проблем молодих сімей. 
Halyna MYKHAILYSHYN, orcid.org/0000-0001-7038-057X, Doctor of Philosophy, Professor, Vice-rector for Scientific and Pedagogical Work Vasyl Stefanyk Precarpathian National University (Ivano-Frankivsk,Ukraine)halyna.mykhailyshyn@pnu.edu.ua

Myroslava DOVHA, orcid.org/0000-0003-0564-123X Graduate Student at the Department of Theory and Methods of Preschool and Special Education Vasyl Stefanyk Precarpathian National University (Ivano-Frankivsk, Ukraine) mirosya29@meta.ua

\section{ANALYSIS OF LIFE PROBLEMS OF YOUNG FAMILIES IN SOCIETY}

At the present stage of development of Ukrainian society, appropriate transformational changes have taken place in its various social institutions, among which the institution of the young family is the most vulnerable. Transformational changes among young families are manifested in the center of preservation and restoration of family values, an increase in the number of divorced families, illegitimate births, lower living standards of family life. Because it is young families who react most quickly and painfully to such changes caused by external circumstances, which in turn give rise to internal family contradictions. And this in turn leads to a number of family problems that are interconnected and arise from each other. Therefore, we considered and analyzed the problems that arise in young families: functional problems (material and economic, housing, reproductive, communicative, educational, recreational), the problems of young families (the problem of creating, maintaining and expanding a family), the problem of conflict and one of the most important problems is the social and legal protection of young families by the state.

The system of social and legal protection of the institution of the family in other developed countries is considered, after all, this system includes the usual minimum guarantees and measures for the economic stability of young families. The social and legal protection in the Ukrainian society, which needs to be expanded, regulated and implemented at the legislative level, is analyzed. Because, without a well-thought-out family policy and protection of families, one should not expect positive changes in the institution of the family.

The statistics of the surveyed young families in Ivano-Frankivsk on the problems that in their opinion are most characteristic of young families and the problems that are present in their family are also given. These problems, which are inherent and present in young families, are reduced to an inadequate level of social and legal protection, which causes a number of all other family problems.

A pyramid of problems of young families is built, which shows the problems from top to bottom that arise in young families and the relationship between them. At the top of the pyramid of problems of young families is social and legal protection as the basis for the protection of the family, according to which the problems of young families are arranged in the following order: the problem of conflict, problems of family formation, functional problems. problems.

Key words: family functions, young families, problems of young families, pyramid of problems of young families.

Постановка проблеми. Проблеми сучасної сім’ї належать до найбільш важливих і актуальних. Дедалі частіше чуємо висловлювання «демографічна катастрофа», «сім'я скоро відімре», заклики «врятуйте сім'ю». Щоправда, є й інші судження: мовляв, нічого небезпечного у сфері сімейних відносин не відбувається. Просто здійснюється поступовий перехід від застарілої моделі сім’ї до нової, що відповідає вимогам сучасного способу життя. Це нібито нормальний розвиток подій, і підстав для занепокоєння з цього приводу немає. I все ж підстав для тривоги більше ніж достатньо. Сім'я дійсно перебуває в кризовому становищі. I причиною цього $є$ соціальні зміни, зростання мобільності населення, урбанізація, секуляризація та інші чинники, що призводять до розхитування «сімейних цінностей».
Ці та низка інших чинників зумовили також падіння сім'ї як соціального інституту суспільства, зміну їі місця в ціннісних орієнтаціях (Інформаційний калейдоскоп, 2014: 9). I саме зміна цих ціннісних орієнтацій призводить до нерозуміння та знецінення значення сім'ї, ролі кожного їі члена на побудову щасливого сімейного життя.

У результаті різних соціальних змін, які швидко відбуваються в розвитку нашого українського суспільства, сім'я практично не встигає адаптуватися до них, що своєю чергою призводить до появи різного роду сімейних проблем, які є взаємопов'язаними і впливають на сім'ю (особливо новостворену молоду сім'ю, де закладаються основи формування та збереження цінностей у кожній конкретній сім'і), тобто призводить до видозмін та падіння інституту сім’ї загалом. 
Аналіз досліджень. Першим в Україні дослідженням, присвяченим вивченню проблем молодої сім'ї, була робота «Молода сім'я в Україні 90-х» (керівник Ю. М. Якубова (Ю. М. Галустян)), здійснена УкрНДІ молоді. Дослідження мало на меті вивчити проблеми одного покоління молодих сімей (Якубова, 2011: 217). Питаннями молодих сімей цікавилися такі науковці: Т. Алєксєєнко, Т. Гурко, А. Капська, Ю. Якубова тощо. Дослідження різного роду проблем здійснювали: А. Антонов, В. Борисов, С. Дармодехін, О. Карабанова, С. Ничипоренко, В. Сисенко тощо.

Сучасні наукові дослідження соціальних проблем молодих сімей в Україні представлені в роботах українських дослідників, наукові пошуки яких розкривають теоретичні основи соціальнопедагогічної діяльності сім'ї (І. Звєрєва, Г. Лактіонова, Л. Штефан, С. Харченко), характеризують напрями соціально-педагогічної роботи зі сім'єю - підготовки молоді до сімейного життя (В. Кравець), формування усвідомленого батьківства і батьківської компетентності (Т. Алексєєнко, 3. Зайцева), культури сімейних стосунків і педагогічної культури батьків (В. Костів, М. Стельмахович) (Архипова та ін., 2011: 2).

Мета статті - проаналізувати функції та проблеми у створених сучасних молодих сім'ях та ві результаті проведеного опитування серед молодих сімей Івано-Франківська побудувати «піраміду проблем молодих сімей».

Виклад основаного матеріалу. Для того, щоб проаналізувати всі проблеми, які виникають уі сучасній молодій сім'ї, іï необхідно розглядати у взаємозв'язку з соціальним оточенням, до якого, перш за все, належать батьки подружжя, їх найближчі родичі, а також ті соціальні інститути, зі якими молода сім'я змушена вступати в контакт для підтримки життєзабезпечення, розвитку та реального виконання своїх функцій (Костровець, 2012: 454a).

Сімейні проблеми можна проаналізувати через наведені нижче основні функції сім'ї (Алєксєєнко, 2002: 55-72; Балакірева, 2002: 82-94).

1. Матеріально-економічна функція, яку становить сімейний бюджет, організація споживчої діяльності, участь у суспільному виробництві, здобуття професії, відновлення втрачених наі виробництві сил.

Важливою проблемою сім'ї є іiі матеріальне забезпечення - загальний рівень життя, в який входять і рівень заробітної плати, і забезпеченість товарами широкого вжитку, благоустрій побуту, організація вільного часу тощо. Зрозуміло, що проблема матеріальної забезпеченості сім'ї не єдина для нормального її функціонування, але це той фундамент, який дає змогу кожній сім'ї отримати все необхідне для усіх iï членів, насамперед, для дітей (Кратохвіл, 2000: 67).

Нині молода сім'я опинилася в досить складних матеріальних та побутових умовах внаслідок низького рівня життя в країні, нестабільність заробітків. Соціально-економічні перетворення досить суттєво вплинули на добробут української родини, особливо це позначилося на економіці молодих родин, що мають дітей. Гострою залишається проблема доступу до базових можливостей розвитку людського потенціалу: продуктивної зайнятості, освіти, медичного обслуговування (Соціально-педагогічна робота: 10a).

2. Житлово-побутова функція - це забезпечення сім'ї житлом, ведення домашнього господарства, організація домашнього побуту.

Значні зміни поліпшення становища сімей передбачені в житловому законодавстві. У процесі виділення земельних ділянок для забудови органи місцевого самоврядування затверджують квоти на ділянки, які надаються молодим сім'ям під будівництво житла. Молодим сім'ям та молодим громадянам гарантується отримання пільгових довгострокових державних кредитів на будівництво й одержання житлових будинків і квартир, на оплату вступних пайових внесків до молодіжних житлових комплексів, житлово-будівельних кооперативів, а також на облаштування домашнім господарством (Ничипоренко, 2011: 36а).

Нині житлова та матеріальна проблема серед молодих сімей стоїть на першому місці зміцнення сімейних стосунків, оскільки більшість молодих сімей не мають власного житла, винаймають квартиру або проживають разом із батьками. Якщо колись тенденція була прийнятою до спільного проживання разом із батьками, то нині молоді люди прагнуть окремо проживати. Щодо матеріальної проблеми, то вона гостро проявляється уі працевлаштуванні молодих людей, де здебільшого заробітна плата $є$ низькою. Це своєю чергою штовхає молодих сімей працювати далеко від дому, а в деяких (в більшості ) випадках - i за кордоном. Постійна відсутність вдома тягне за собою низку інших внутрішніх, психологічних проблем: зникають взаєморозуміння, повага, любов, доброзичливі стосунки, тобто відбувається знецінення ролі сім'ї.

3. Репродуктивна (демографічна) функція сім'ї полягає у відтворенні життя, продовженні людського роду, тобто в народженні дітей.

Ця функція включає себе елементи всіх інших функцій, оскільки сім'я бере участь не лише в кількісному, але й в якісному відтворенні населення. 
Якщо сім'я має кілька дітей, то створюються природні умови для формування повноцінного сімейного колективу, відбувається активне взаємовиховання дітей, к житті кожної дитини природним чином функціонують колективізм, співпереживання, солідарність, почуття товариськості, дружби. Особливістю сучасної молодої сім'ї є іiї малодітність (більшість сімей має одну дитину), бездітність, відкладання народження дітей на невизначений період (Карабанова, 2001a).

Водночас заходи, що здійснюються органами державної влади, зокрема щодо стимулювання народжуваності в Україні, не забезпечують рівень відтворення населення, незважаючи на певне збільшення рівня народжуваності. Найпоширенішим типом сім'ї є однодітна. При цьому кількість сімей, які обмежуються народженням і вихованням лише однієї дитини, з року в рік збільшується, а кількість сімей із трьома і більше дітьми зменшується. Основною причиною такої ситуації $\epsilon$ недостатність матеріального забезпечення, відсутність належних житлових та інших необхідних умов для забезпечення майбутнього дітей, належної пропаганди сімейних цінностей (Школьнік).

4. Комунікативна функція сім'ї передбачає створення сприятливого сімейного мікроклімату, необхідного для психічно-емоційного відтворення сил членів сім'ї, внутрішньосімейного спілкування подружжя, батьків і дітей, сім'ї та оточуючого мікро- i макросередовища, а також iii спілкування 3 духовними та інтелектуальними надбаннями суспільства (засоби масової інформації, література, мистецтво тощо).

Сімейне спілкування має свої особливості: 1) інтимність, камерність, близькість партнерів; 2) родина сприймає своїх членів багатогранно, повністю, допомагаючи кожному засвоювати та успішно виконувати ролі та обов'язки у «зовнішньому світі»; 3) єдність процесів розвитку, навчання та виховання; 4) завдяки родині пристосування людини до нових соціальних умов або повна соціалізація відбувається у порівняно стабільному соціальному середовищі (Семеченко, Заслуженюк, 1998: 217a).

Це - позитив сімейного спілкування. Проте $\epsilon$ й негатив - особливості, які ускладнюють стосунки, особливо між молодими батьками та дітьми: 1) у сім’ї людина послаблює контроль, не приховує роздратування, поганого настрою, відверта зі своїми близькими; 2) взаємодія уі сімейному спілкуванні може бути обмеженою, оскільки члени сім'ї вже задовольнили свої комунікаційні потреби і прагнуть спокою; 3) спілкуванні в сім’ї відбувається на тлі щоденних турбот, що нерідко знецінює його зміст. Буденність стосун- ків, постійна заклопотаність батьків може бути нестерпною для дитини; 4) сімейні стосунки ускладнює відсутність у більшості молодих батьків психолого-педагогічних знань та досвіду організації стосунків; 5) недооцінка налагодження стосунків уі родині призводить або до ії розпаду, або до постійних конфліктів і ускладнень; 6) надзвичайно важливим компонентом спілкування $€$ мова. Мова спілкування сучасних молодих батьків із дітьми має свої характерні ознаки: здебільшого вона непослідовна, 3 певною мірою роздратування, інколи нагадує муштру (Семеченко, Заслуженюк, 1998: 217b).

5. Виховна функція полягає у передачі дітям дорослими членами сім'ї соціального досвіду.

Проблему виховання в сім'ї, у тому числі і молодій, значно ускладнюють соціально-економічні перетворення в нашій країні, які проявляються в матеріальних труднощах, проблемах житлово-побутового характеру. 3 огляду на низький рівень підготовки до сімейного життя, відсутність досвіду виховання, зазначені вище проблеми та труднощі значно знижують виховний потенціал сучасної молодої сім’ї, від якого залежить успіх виховання. Як компоненти виховного потенціалу сім'ї можна виділити такі складники: 1) чисельність та структура сім'і; 2) психологічна атмосфера, характер сімейного спілкування; 3) життевий та професійний досвід батьків, рівень їхньої освіченості та педагогічної культури; 4) розподіл обов'язків у сім'ї (в тому числі виховних); 5) і матеріальні та побутові умови сім'ї; 6) організація сімейного дозвілля; 7) взаємозв'язок з іншими соціальними інститутами (Капська, 2000: 56).

Одним із компонентів виховного потенціалу сім'ї є проблема розподілу обов'язків у сім’ї, зокрема виховних. Уже неодноразово зазначалося, що в процесі розподілу сімейних обов' язків спостерігається нерівний розподіл сімейних обов'язків між чоловіком та дружиною. Нині жінки відчувають на собі подвійне навантаження, адже вони виконують роль не лише матері, а й виступають рівноправним членом суспільства. Таке навантаження призводить до психічної та фізичної втоми, як наслідок, жінка стає більш вразливою, заклопотаною, що не може не позначитися на психологічному кліматі в сім'ї, вихованні дитини. Підвищена зайнятість батька і матері зумовлена необхідністю матеріально-економічного становлення сім’і (Соціально-педагогічна робота).

На жаль, педагогічна культура сучасних молодих батьків залишається на низькому рівні. Це зумовлено наявністю багатьох проблем, пов'язаних із функціонуванням молодої сім'ї: низьким рівнем моральної та матеріальної готов- 
ності молоді до створення сім'ї та виконання виховної функції; тенденцією до омолодження шлюбу i, як наслідок, відсутністю життєвого досвіду в молодих батьків; недооцінкою молоддю ролі сім'ї в житті дитини і суспільства загалом відсутністю досвіду виховання в молодих батьків, пов'язаного 3 народженням дитини-первістка та орієнтацією на одну дитину, що не дозволяє відтворити природну школу підготовки батьків; професійною зайнятістю батьків (особливо матері) та зменшенням часу на спілкування та виховання дитини (Соціально-педагогічна робота).

3 метою доцільної організації спілкування в сім'ї та виховання дітей батьки мають показувати свою любов один до одного та до дітей, яка має бути однаковою до всіх, оскільки однакова любов до дітей, повага батьків однин до одного, рівність поглядів та думок допоможе дитині навчитися поважати та любити своїх батьків, братів та сестер. Це своєю чергою призведе до довіри один до одного та до злагоди в сімейному житті, головним мотивом яких буде виступати любов.

6. Рекреативна функція сім'ї - це організація вільного часу та відпочинку сім’ї. Вона виконує роль збереження сім'ї як цілісної одиниці, зміцнює сім'ю, закріплює кращі традиції, має велике значення у вихованні дітей, емоційному єднанні подружжя (Ворона, Шульга, 2001: 74-76).

Деяка частина сучасних молодих сімей позбавляється можливості духовного розвитку своїх членів. Незадовільні житлові умови і вимушена необхідність проводити своє дозвілля здебільшого вдома можуть призводити до роздратованості, негативного стереотипу поведінки в сім'ї, конфліктів, незадоволеності шлюбом (Карабанова, 2001b).

Окрім проблем функціональних, варто розкрити і проблеми становлення молодої сім'ї, які $€$ взаємопов'язаними і випливають одні з одних, зокрема проблема створення сім'ї, іiі збереження та розширення.

Процес створення сім'ї надзвичайно складний. Третина конфліктів у молодих сім'ях пов'язана 3 помилковими мотивами вступу в шлюб (шлюб не з любові, з легковажності, змушені шлюби тощо), що призводить до швидких розлучень. У багатьох сім'ях можливість створення молоддю власної сім'ї обмежується і сімейними проблемами старшого покоління (незаміжньою матір'ю, неодруженим батьком) (Костровець, 2012: 454b).

Період становлення молодої $є$ найбільш ризикованим періодом сімейного життя. Адже саме в цей період подружжя намагається знайти спільну мову на побутовому рівні, визначитися із сімейними ролями, обов'язками, правилами та моральними цінностями (Літяга, Михалкіна). Тому саме для побудови нормальних сімейних стосунків впливає проблема нерозуміння значення самого поняття «сім'я».

Щодо збереження сім'ї, то це одна 3 найважливіших проблем дестабілізації сімейних стосунків. Для прикладу, в Івано-Франківській області, то, за статистичними даними, у 2018 році було укладено приблизно 7687 шлюбів, з яких 3073 розпалося, 3 них у самому Івано-Франківську укладено $2784 \mathrm{i}$ шлюби, серед них 590 розлучень. Багато $\epsilon$ таких сімей, в яких формально сім'я зберігається, але функціонально її немає або вона не функціонує певним чином.

Варто означити таку сімейну проблему, як поява конфлікту, особливо в молодих сім'ях, коли починають формуватися сімейні стосунки. В. Сисенко дійшов висновку, що розбіжності та конфліктні ситуації грунтуються здебільшого на таких причинах (Капська, 2006: 184): незадоволеність сексуальних потреб одного з подружжя; незадоволеність потреби сили і значимості власного «Я» (порушення почуття власної гідності зі боку іншого партнера, його неповажне ставлення, образи, критика); незадоволеність потреби одного $з$ подружжя або кожного 3 них у позитивних емоціях (відсутність лагідності, ніжності, турботи, уваги і розуміння, психологічне відчуження подружжя один від одного); пристосування одного 3 подружжя до спиртних напоїв, азартних ігор; фінансові розбіжності між подружжям (питання сімейного бюджету, утримання сім'ї, внеску кожного члена в ії матеріальне забезпечення); незадоволеність у потребі взаємної допомоги, взаємопідтримці, потреби у співробітництві, пов'язана з розподілом праці у сім'ї, веденням домашнього господарства, доглядом за дітьми; різні потреби і інтереси проведення відпочинку, дозвілля, розбіжності в захопленнях.

Щодо опитуваних молодих сімей у м. ІваноФранківськ у період з вересня 2019 року по травень 2020 року, то в ньому взяло участь 73 особи (42 жінки і 31 чоловік) із молодих сімей.

За результати опитування на запитання 3 якими проблемами найчастіше стикаються молодi ciм' $i$ ? опитувані визначили: житлово-побутова проблема (30 осіб - 41,1\%); матеріально-економічна проблема (29 - 39,7\%); проблема роздратування, незадоволеності шлюбом та нерозуміння справжнього значення сім'ї (13 - 17,8\%); комунікативна проблема $(9-12,3 \%)$ та дезорганізація шлюбних відносин $(1-1,4 \%)$, яку зараховуємо до комунікативної проблеми; репродуктивна проблема (5 - 6,8\%); проблема появи конфлікту $(5-6,8 \%)$; виховна проблема $(4-5,5 \%)$; рекреативна проблема $(3-4,1 \%)$; проблема соці- 
ально-правового захисту $(2-2,7 \%)$. Поодинокі відповіді (по 1,4\%): проблема створення, збереження та розширення сім'ї; комунікативна та виховна проблеми; соціально-правова, поява конфлікту та комунікативні проблеми; усі вище перераховані (рис. 1).

Як ми бачимо, серед проблем, з якими зустрічаються молоді сім'ї найбільше, визначено уі 41,1\% житлово-побутову проблему та 39,7\% матеріально-економічну проблему. Ці проблеми свідчать про відсутність соціально-правового захисту з боку держави щодо молодих сімей, що виступає однією із проблем серед сімей. Якщо б держава на належному рівні сприяла високому рівню життєдіяльності сімей, надавала їм відповідну допомогу, доступне кредитування, то матеріально-економічної та житлово-побутової проблеми можна було б уникнути, а за нею і зменшити низку інших проблем.

А щодо наявності проблем в їхніх сім'ях, то картина дещо інша. На запитання Які проблеми $\epsilon$ наявними у Вашій сім'ї? молоді сім'ї відповіли так: немає проблем у 22 осіб (30,1\%); матеріально-економічна проблема у 12 осіб $(16,4 \%)$ : економічна, фінансові, недостатнє матеріальне забезпечення; проблема появи конфлікту у 9 осіб
(12,3\%): конфлікти, конфлікти через все, конфлікти на рівному місці, часті суперечки; житлово-побутова проблема наявна в 7 осіб $(9,6 \%)$; рекреативна проблема присутня в 5 (6,8\%): не завжди вистачає часу на відпочинок, проблема 3 організації вільного часу, мало часу проводимо разом. Визначено такі проблеми: комунікативна проблема $(1-1,4 \%)$; нерозуміння $(1-1,4 \%)$; одноманітність $(1-1,4 \%)$; ревнощі $(2-2,7 \%)$; часті сварки через мене батька $(1-1,4 \%)$; не завжди живемо разом (1 - 1,4\%); алкоголь $(1-1,4 \%)$; впертість (невміння сприймати чужу думку) $1(1,4 \%)$; важко відповісти $(1-1,4 \%)$. А деяких молодих сім'ях кілька проблем $(8-11 \%)$ : брак вільного часу, мало спілкування; житлово-побутова та репродуктивна проблеми; житлово-побутова, репродуктивна, проблема появи конфлікту; конфлікти і нерозуміння; матеріальні та житлові проблеми; матеріальна проблема та брак вільного часу; проблема появи конфлікту та комунікативна проблема; проблема появи конфлікту та житловопобутові проблеми (рис. 2).

Тому за цим питанням можна зробити висновок, що в молодих сімей найбільш вираженою $\epsilon$ матеріально-економічна, житлово-побутова та проблема появи конфлікту. В деяких сім'ях є кілька

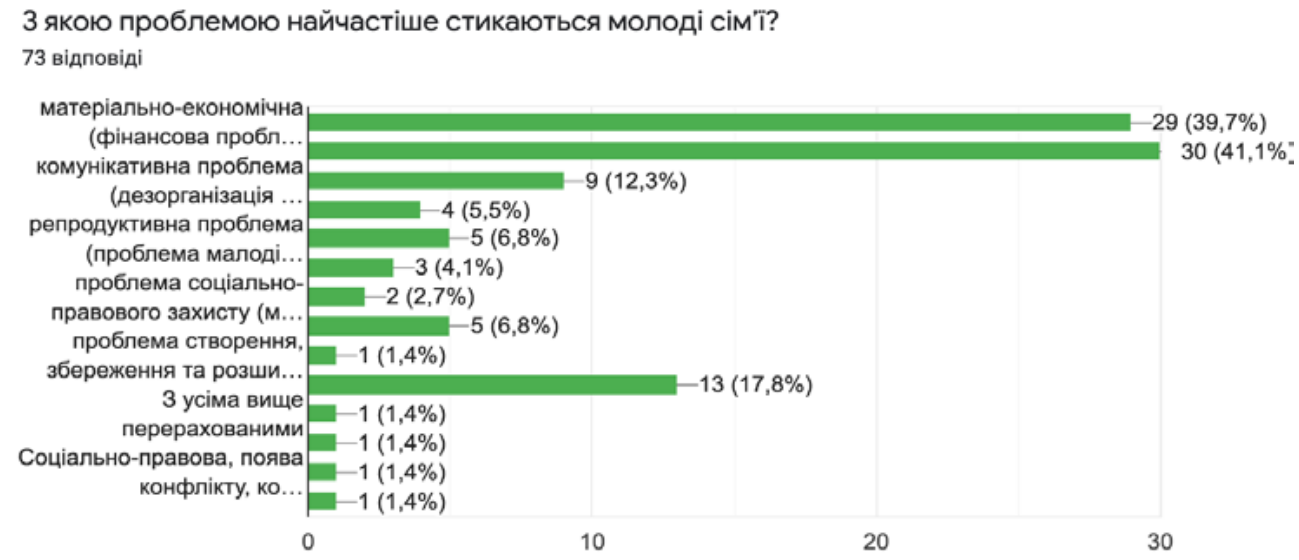

Рис. 1. Відповіді на запитання «3 якою проблемою найчастіше стикаються молоді сім'ї?»

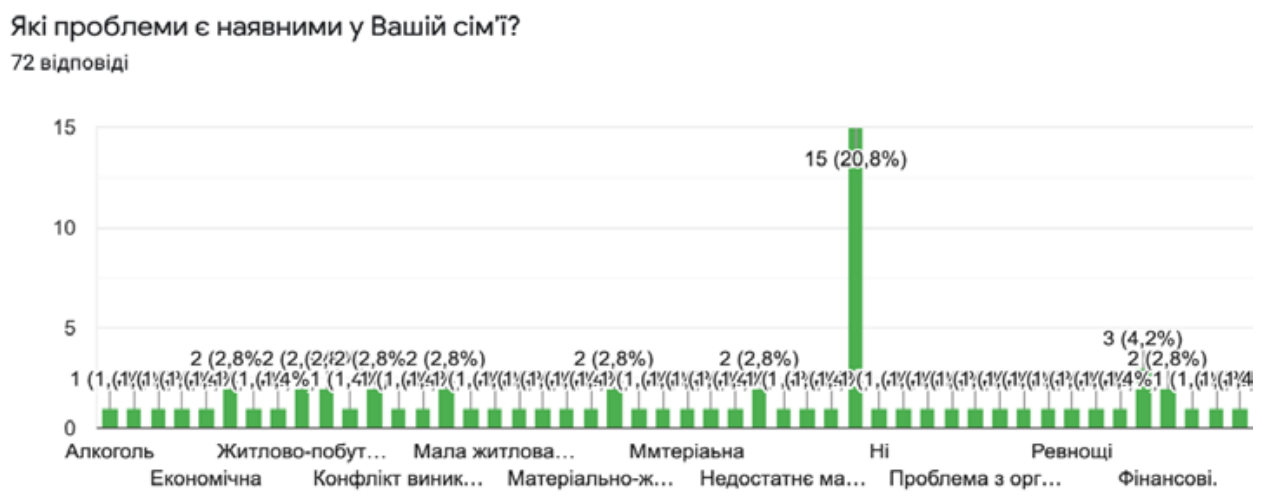

Рис. 2. Відповіді на запитання «Які проблеми наявні у Вашій сім'ї?» 
проблем. Така проблема, як поява конфлікту, виникає на основі інших проблем, що виникають між людьми в процесі їхнього спільного життя разом. Якщо би в нас на належному рівні здійснювався соціально-правовий захист із боку держави, то таку проблему, як житлова та матеріальна, можна було б зменшити та подолати, відповідно, зберегти новостворену сім'ю. А оскільки в нас відповідний соціально-правовий захист відсутній, ці проблеми є і спричиняють конфліктну ситуацію.

Варто виділити таку досить важливу проблему, як соціально-правовий захист із боку держави.

Основними завданнями державної політики щодо сімей $\epsilon$ : забезпечення правового та соціального захисту сім' $і ;$; сприяння високому рівню життєдіяльності сім'ї, належних умов для фізичного, інтелектуального, морально-етичного, освітнього та духовного розвитку дітей; розвиток високої психологічної та педагогічної культури молодої сім'ї на принципах національних звичаїв, педагогічної доктрини, кращого світової практики виховання дітей у сім'ї і функціонування сім'ї; формування в молоді відповідального ставлення до репродуктивного здоров'я, планування сім'ї; пропаганда здорового способу життя, відповідального батьківства та безпечного материнства; всебічна державна допомога зусиль самих сімей, батьків або осіб, які їх замінюють, у забезпеченні сприятливих умов для виховання, освіти і розвитку дітей (Ничипоренко, 2011: 40b). Таким чином, державна сімейна політика зорієнтована на підтримку молодої сім'ї і має створити умови для iii подальшого розвитку, тобто сприяти нормаль- ному функціонуванню молодої сім'ї та дати змогу реалізувати ії інтереси.

Без продуманої і реалістичної сімейної політики, розширення соціально-правового, економічного захисту молодих сімей та сімей із дітьми навряд чи можна чекати зміни демографічної ситуації на кращу. Така політика має включати в себе систему звичних мінімальних гарантій (допомоги, компенсації, натуральної допомоги, охорони здоров'я матері і дитини, дошкільного виховання і освіти), а також заходи, що стимулюють економічну самостійність сім'ї (пільгові кредити, податкові пільги, практична допомога в розвитку сімейного підприємництва, малих сімейних підприємств і т.п.) (Костровець, 2012: 458 с).

Тому для розуміння рівня підтримки інституту сім’ї в інших країнах та засобів, які задіяні в цьому процесі, наведено окремі виразні приклади.

1. Франція: податкові пільги; субсидії та підтримка; впровадження з 1921 р. та дія програми «Велика сім'я». Приклад: сім'я з чотирма дітьми звільняється від оподаткування незалежно від матеріального статку всієї сім'ї.

2. Німеччина: податкові бонуси; субсидії та підтримка; безплатна шкільна та університетська освіта.

3. Польща: видатки багатодітним сім'ям; безплатнна дошкільна, шкільна та університетська освіта. Приклад: подвійні видатки за наявності в сім’ї дитини інваліда, якщо один із батьків за ним доглядає і не працює.

4. Чехія: субсидії та підтримка; зменшення пенсійного віку. Приклад: кожна новонароджена

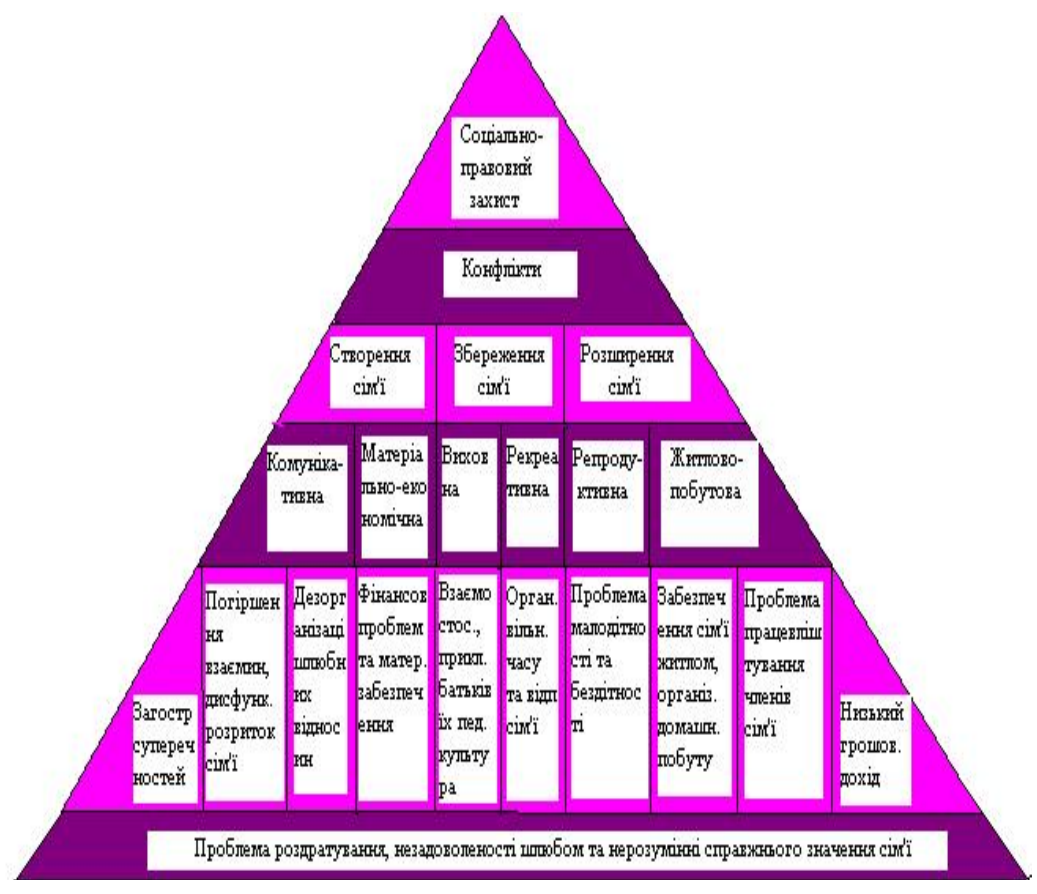

Рис. 3. Піраміда проблем молодих сімей 
дитина зменшує на один рік пенсійний вік матері (Ващук, 2019: 39a).

5. Японія: оплачувані відпустки дородові, після народження дитини та по догляду за дитиною за кошти держави, спецфондів і працедавців. Одноразові дитячі виплати, пенсії по втраті годувальника. Допомога $з$ боку працедавців, надання житла в оренду, існування фондів взаємодопомоги (при народженні дитини, вступі дитини до школи та ін.). Надання пільг для користування медичними послугами.

6. Сполучені Штати Америки: безплатна шкільна освіта; безплатна або пільгова вища освіта за рахунок держави; дотації на отримання медичних та житлових послуг.

7. Канада: існування двох рівнів (федеральний та провінційний). Види: оплачувані відпустки окремо для обох батьків; безплатна освіта; щомісячні виплати; одноразові виплати; звільнення від оподаткування. Рівень виплат та допомоги залежить від доходів сім'ї та кількості дітей.

За результатами дослідження мають найбільш розгалужену системупідтримкиінститутусім'їтакі країни, як Швеція та Фінляндія (Ващук, 2019: 40b).

Отже, як ми бачимо, соціально-правовий захист інституту сім’ї в інших країнах на високому рівні і проявляється в забезпеченні та розвитку усіх сімейних сфер і різних форм підтримки. Тому соціальноправовий захист молодих сімей в українському суспільстві має сприяти не тільки забезпеченню матеріального становища, але й допомогти реалізувати трудові, сімейні та інші права молодих людей, надавати відповідні пільги, допомогти затвердженому на врегульованому законодавчому рівні.

Щодо розглянутих проблем становлення та функціонування молодої сім'ї, які є взаємопов'язаними та випливають одні на одних, нами розроблена піраміда проблем молодих сімей (рис. 3) для того, щоб показати, як відбувається взаємодія між ними і як одні проблеми породжують інші сімейні проблеми.

Тому, як ми бачимо, нами проблема соціальноправового захисту виділена у піраміді на самому верху, оскільки якщо б захист із боку держави відбувався на належному рівні, як в інших країнах, який би відповідав рівню розвитку та життю українських сімей, це призвело б до зменшення, а можливо, і до не появи деяких проблем, таких як матеріально-економічна, житлово-побутова, демографічна, рекреаційна проблема, проблема появи конфлікту тощо.

На другий план нами виділено проблему появи конфлікту, адже усі проблеми, які знаходяться під ним, призводять до непорозумінь. А вже під ним проблеми становлення сім'ї, що поділяються на проблеми створення, збереження та розширення сім'ї. А під ними виникають відповідно функціональні проблеми, зокрема матеріально-економічна, житлово-побутова, виховна, комунікативна, репродуктивна та рекреаційна. I вони своєю чергою містять низку проблем, розташованих під ними. Наприклад, якщо в молодій сім'ї є комунікативна проблема, то вона рано чи пізно призведе до появи таких проблем, наведеними нами нижче, як проблема загострення суперечностей, погіршення взаємин, дисфункціональний розвиток сім'ї та дезорганізація шлюбних відносин.

Безумовно, зазначені проблеми впливають на незадоволення сімейним життям та виступають як проблема молодої сім'ї щодо постійного роздратування молодих людей.

Висновки. Таким чином, проблеми молодих сімей постають у формі піраміди, де є верхівка і яка поділяється на менші частини. Так і проблеми молодих сімей випливають одні з одних і тягнуть за собою одна одну, сскільки постійне погіршення рівня життя спричинене зростанням цін, поганим медичним обслуговуванням, відсутністю міцного соціально-правового захисту 3 боку держави щодо підтримки молодих сімей та позитивні реформи на покращення життя, безробіття чи його загроза, труднощі із житлом тощо, що все це призводить до нестабільності молодих сімей та невпевненості у майбутньому. На перший план виступає матеріальна сторона, професійний розвиток, а сімейні цінності залишаються незрілими та досить суперечливими між молодими людьми в їхньому спільному сімейному житті. А це все водночас впливає на духовну сторону сім'ї та спричиняє дискомфорт у сімейних стосунках, погане самопочуття та психологічний мікроклімат в усіх її членів.

\section{СПИСОК ВИКОРИСТАНИХ ДЖЕРЕЛ}

1. Алєксєєнко Т. Ф. Виховний потенціал сім'ї в сучасних умовах. Київ : Український соціум, 2002. 143 с.

2. Архипова С. П., Майборда Г. Я., Тютюнник О. В. Соціально-педагогічні технології роботи з неблагополучними сім'ями. Методи та технології роботи соціального педагога : навч. посібник. Київ : Слово, 2011. С. 242-261.

3. Балакірева М. О. Молоде покоління нової України: ескіз соціального портрету : навч. посібник. Київ : ЗнанняПреc, $2002.313 \mathrm{c}$.

4. Ващук О. П. Міжнародний досвід сприяння інституту сім'ї. Розвиток сімейної політики міста : статті, за результатами Всеукраїнської науково-практичної конференції, 17 травня 2019 р. Херсон : Видавничий дім «Гельветика», 2019. С. 38-43.

5. Інформаційний калейдоскоп «Модель сучасної родини». URL: http://www.biblioteka.lviv.ua/files/family.pdf. 
6. Капська А. Й. Молода сім’я: проблеми та умови її становлення. Київ : ДЦССМ, 2006. 184 с.

7. Карабанова О.А. Психология семейных отношений : учебн. пособ. Москва:Самара:Изд-во СИОКПП, 2001. 119с.

8. Костровець Л. Б. Значення молодих сімей у процесі формування повноцінного українського суспільства. Комунальне господарство міст : науково-технічний збірник. 2012. № 102. С. 452-459.

9. Кратохвил С. В. Психотерапия семейно-сексуальных дисгармоний. Москва, 2000. 322 с.

10. Літяга I., Михалкіна Р. Робота 3 молодими сім'ями, які потребують соціальної підтримки. URL: http://eprints.zu.edu.ua/25291/1/Руслана Михалкіна.pdf.

11. Молода сім'я України 90-х / Ю. Якубова, Л. Волинець, Н. Лавриненко, Г. Онищенко; за ред. Якубової Ю. М. Київ : А.Л.Д., 1996. 104 с.

12. Ничипоренко С. В. Молодіжна сімейна політика в Україні. Умань : Видавець «Сочінський», 2011.217 с.

13. Селиченко В. А., Заслуженюк В. С. Психологія та педагогіка сімейного спілкування : навч. посіб. для студентів вищ. навч. закладів. Київ : Логос, 1998. 217 с.

14.Соціально-педагогічна робота з молодими сім'ями в умовах малого міста. URL: https://vipsoft.blob.core. windows.net/contest/e39d143750c099e70b02ebfd9aaa1056.pdf

15. Технології соціально-профілактичної роботи : навч. посібник / За заг. ред. проф. А. Й. Капської. Київ : Логос, 2000. $372 \mathrm{c}$.

16. Українське суспільство: десять років незалежності (соціальний моніторинг та коментар науковців) / За ред. В. М. Ворони, М. О. Шульги. Київ : Інститут соціології НАН України, 2001. 662 с.

17. Школьнік М. В. Проблеми створення молодих сімей молоддю в Україні. URL: https://conferences.vntu.edu.ua/ index.php/all-hum/all-hum-2017/paper/download/2073/1601.

\section{REFERENCES}

1. Alekseenko T. F. Vykhovnyy potentsial sim'yi v suchasnykh umovakh. [Educational potential of the family in modern conditions]. Kyiv: Ukrainian society, 2002. 143 p. [in Ukrainian].

2. Arkhipova S. P, Mayborda G. Ya., Tyutyunnik O. V. Sotsialno-pedahohichni tekhnolohiyi roboty z neblahopoluchnymy simyamy. Metody ta tekhnolohiyi roboty sotsialnoho pedahoha: textbook. [Socio-pedagogical technologies of work with disadvantaged families. Methods and technologies of social pedagogue: textbook]. Kyiv: Slovo, 2011. pp. 242-261 [in Ukrainian].

3. Balakireva M. O. Molode pokolinnya novoyi Ukrayiny: eskiz sotsialnoho portretu: textbook. [The young generation of the new Ukraine: a sketch of a social portrait: textbook]. Kyiv: Znannia-Press, 2002. 313 p. [in Ukrainian].

4. Vashchuk O. P. Mizhnarodnyy dosvid spryyannya instytutu simyi. Rozvytok simeynoyi polityky mista: statti, za rezultatamy Vseukrayinskoyi naukovo-praktychnoyi konferentsiyi , 17 travnya 2019 r. [International experience in promoting the institution of the family. Development of family policy of the city: articles, based on the results of the All-Ukrainian scientific-practical conference, May 17, 2019]. Kherson: Helvetica Publishing House, 2019. Pp. 38-43 [in Ukrainian].

5. Informatsiynyy kaleydoskop "Model suchasnoyi rodyny". [Information kaleidoscope "Model of the modern family"]. URL:http://www.biblioteka.lviv.ua/files/family.pdf. [in Ukrainian].

6. Kapska A. Y. Moloda sim'ya: problemy ta umovy yiyi stanovlennya. [Young family: problems and conditions of its formation]. Kyiv : DCSSM, 2006. 184 p. [in Ukrainian].

7. Karabanova O. A. Psikhologiya semeynykhotnosheniy: textbook [Psychology of family relations: textbook]. Moscow: Samara: SIOKPP Publishing House, 2001. 119 p. [in Russian].

8. Kostrovets L. B. Znachennya molodykh simey u protsesi formuvannya povnotsinnoho ukrayinskoho suspilstva. [The importance of young families in the process of forming a full-fledged Ukrainian society]. Municipal services of cities: scientific and technical collection, 2012. № 102. Pp. 452-459 [in Ukrainian].

9.Kratokhvil S.V. Psikhoterapiya semeyno-seksual'nykh disgarmoniy. [Psychotherapy of family and sexual disharmonies]. M., 2000. 322 p. [in Russian].

10. Lityaga I., Mikhalkina R. Robota z molodymy simyamy, yaki potrebuyut sotsialnoyi pidtrymky. [Work with young families in need of social support]. URL: http://eprints.zu.edu.ua/25291/1/Руслана Михалкина.pdf. [in Ukrainian].

11. Moloda sim'ya Ukrayiny 90-kh [The young family of Ukraine of the 90s] / Yu. Yakubova, L. Volynets, N. Lavrinenko, G. Onyschenko; for order. Yakubova Y. M. Kyiv: ALD, 1996. 104 p. [in Ukrainian].

12. Nychyporenko S. V. Molodizhna simeyna polityka v Ukrayini. [Youth family policy in Ukraine]. Uman: Sochinsky Publisher, 2011. 217 p. [in Ukrainian].

13. Selichenko V. A., Zasluzhenyuk V. S. Psykholohiya ta pedahohika simeynoho spilkuvanny: Textbook for students of higher institutions. [Psychology and pedagogy of family communication: Textbook for students of higher institutions]. K.: Logos, 1998. 217 p. [in Ukrainian].

14. Sotsialno-pedahohichna robota $\mathrm{z}$ molodymy simyamy v umovakh maloho mista. [Socio-pedagogical work with young families in a small town]. URL: https://vipsoft.blob.core.windows.net/contest/e39d143750c099e70b02ebfd9aaa1056.pdf. [in Ukrainian].

15. Tekhnolohiyi sotsialno-profilaktychnoyi roboty: textbook. Manual. [Technologies of social and preventive work: textbook. Manual] / Ed. prof. A. Y. Kapska . Kyiv: Logos, 2000. 372 p. [in Ukrainian].

16. Ukrayinske suspilstvo: desyat rokiv nezalezhnosti (sotsialnyy monitorynh ta komentar naukovtsiv). [Ukrainian society: ten years of independence (social monitoring and commentary of scientists)] / Ed. V. M. Voroni, M. O. Shulgi. Kyiv: Institute of Sociology of the National Academy of Sciences of Ukraine, 2001. 662 p. [in Ukrainian].

17. Shkolnik M. V. Prolemy stvorennya molodykh simey moloddyu v Ukrayini. [Problems of creating young families by young people in Ukraine]. URL: https://conferences.vntu.edu.ua/index.php/all-hum/all-hum-2017/paper/download/2073/1601. [in Ukrainian]. 